\title{
Breaking the Paradox of Innovation in Small Businesses through Sustaining and Disruptive Reinvention
}

\author{
Dr Vicki Baard \\ Discipline of Accounting and Finance, School of Business and Informatics, Australian Catholic University \\ Dr Ted Watts ${ }^{\dagger}$ \\ Discipline of Accounting, School of Accounting and Finance, University of Wollongong
}

\begin{abstract}
In 2005 Deloitte Research released a paper examining the phenomenon they refer to as the 'innovation paradox': the inability or reluctance of manufacturing firms to pursue strategies that build the operational capabilities necessary for innovation that will provide both profitability and growth. The report claims that this is due to the rapidly increasing complexity of global markets and the lack of synchronising innovation efforts across their value chain, thus positioning the problem as an important contemporary issue. While the research did not specifically target small and medium enterprises, the implications for this business sector are considerable given their substantial contribution to global economies and their high failure rates in the first three to five years of operation. While not questioning the data in the Deloitte research, this paper does question the assumption that the phenomenon is irreversible and the apparent underlying self-fulfilling prophecy with respect to small to medium enterprises. To demonstrate this the authors draw on a case study of a small manufacturing company in rural New South Wales, Australia, which operated between 1889 and 1983, to show that the breaking of the innovation paradox was successfully achieved by this firm in the late nineteenth and early twentieth century. Applying the case study to the Deloitte model the study demonstrates contemporary similarities by overlaying the Laycock history on the successes / failures identified by Deloitte.
\end{abstract}

Key words: Small business innovation, reinvention, innovation paradox

\footnotetext{
Corresponding author. Mail: Building 40. School of Accounting \& Finance, University of Wollongong. E-mail: Tedw@uow.edu.au

* The authors would like to thank the participants of the Emerging Issues in International Accounting Conference for their helpful comments in the development of this paper. The authors retain all responsibility for the arguments presented and their potential errors.
}

\section{INTRODUCTION}

Deloitte (2005) describes the innovation paradox as the inability or reluctance of manufacturing firms to pursue strategies that build the operational capabilities necessary for innovation to provide both profitability and growth. Their research shows that innovation was the top factor with respect to growth, but the bottom factor with respect to supply chain management. They claim that this is due to the rapidly increasing complexity of global markets and value chains, thus positioning the problem as a contemporary phenomenon.

Relating this specifically to small business renowned for innovation, this paper questions the assumptions that this is a contemporary phenomenon and is a self- fulfilling prophecy. To demonstrate this the authors draw on a case study of a small manufacturing company in rural 
New South Wales, Australia, which operated between 1889 and 1983, to show that the breaking of the innovation paradox was successfully achieved by this firm in the late nineteenth and early twentieth centuries. Applying the case study of Joseph Laycock and Son (Gibson, 1988) to the Deloitte model the study demonstrates contemporary similarities by overlaying the Laycock history on the successes / failures identified by Deloitte. In this way the study demonstrates that by continually reinventing itself, this firm successfully avoided the paradox of innovation.

\section{THE DELOITTE MODEL}

The Deloitte model is premised on four critical outcomes of their research. First, that manufacturers must master the complexity of innovation in order to grow; second, that such innovation is driven by changing customer demands and competitive offerings; third, the need to develop a value chain that builds effectively on the market complexities; and finally, the effective management of the entire product lifecycle. From these outcomes Deloitte identified three decisive steps that can be used to generate profitable growth through innovation.

The first is the task of creating innovation, the act of generating and evaluating ideas. This involves generating ideas or sourcing concepts from outside the organisation, developing business strategies on which to base investment decisions, recognising and understanding the gap between the performance of existing products that satisfy customer demands and proposed new products, and determining the most appropriate organisational model to put the innovation into practice.

The second step is to exploit the innovations created in step one. This involves maximising the innovations growth and profit throughout the product's entire lifecycle. In particular, ensuring profitability of the product through flexibility of design, thus allowing speedy and inexpensive modifications, together with cost-effective service and other downstream activities. In other words, the business must recognise the entire value chain.

Building innovation capabilities for success is the third step. This involves identification and utilisation of four key factors:

- better visibility, both upstream and downstream in the value chain

- flexibility in product designs and platforms that allow for quick modifications of product offerings to meet market demands

- more extensive collaboration with customers to define product requirements, and with suppliers to design components and new materials

- the use of advanced technologies for product lifecycle management, product data management, customer relations management, and advanced planning and scheduling.

\section{LITERATURE REVIEW}

\section{INTRODUCTION}

Innovation is defined as an application of ideas and knowledge to meet current or future market needs or, more specifically, as the ability of a firm to develop a product to satisfy the future needs of customers (Fitzgerald and Moon, 1996). The difference, while subtle, shifts the focus from market needs to customer needs, and simultaneously from business in general to small business specifically. This is significant because small business innovations in the nineteenth and twentieth centuries have outnumbered big business by two to one (Siropolis, 1997). This is mainly due to the ability of small business to concentrate on new products, 
rather than improving existing products, as is generally the case with big business (Hatten, 2006). While the high failure rate of small businesses is well documented small business have often survived, and indeed flourished, through the process of 'creative destruction' or 'disruptive reinvention', which constitutes the replacement of existing products, processes and ideas, and of businesses with new and better ones (Hatten, 2006).

\section{SUSTAINING AND DISRUPTIVE REINVENTION}

Fasenfest and Jacobs (2003) document the case of the automotive industry in southeast Michigan, where a rapidly declining manufacturing sector, overly dependent on one sector of industrial production, transformed itself into a revitalised and restructured high-technology business centre. This transformation of a small business sector represented a shift away from manufacturing centres to technical centres that design and build prototypes, make dies, fixtures and machine tools, and assemble automobiles. Similarly, the small businesses of Richmond, Virginia reinvented themselves from support businesses for the traditional banking, tobacco and manufacturing industries to dynamic players in the information technology, semiconductor and biotech industries (Mosher, 2000).

The two examples cited above are examples of the changing small business landscape during the Twentieth century, and demonstrate the need for sustainable competitive advantage through reinvention based on disruptive innovation. According to Voelpel, Leibold and Tekie (2004), the focus is on the development of new bases of building strategic competitive advantage in order to outperform competitors and leapfrog into new areas of competitive advantage. However, the strategy of reinvention for small businesses predates the Twentieth century. For example Morgenthaler (1989) reports the case of the Warren Feathbone Co. between 1883 and 1989 and its strategic reinvention. The company, established in 1883, manufactured an elastic boning material from finely split turkey quills, which was used to stiffen and shape corsets, collars and bustles in the ladies clothing industry. However, the company fell victim to changing fashions and the development of plastics and, in 1938, reinvented itself, in collaboration with the B.F. Goodrich Co., into a manufacturer of plastic baby pants. Its second reinvention occurred in the late 1960s and early 1970s, when the era of disposable nappies arrived, reducing the use of cloth nappies, upon which the company relied. This reinvention saw the emergence of a manufacturer of baby clothes, a small thriving business that still exists.

The impetus for reinvention is driven by factors within the firm or from the industry of which the firm is part of (Burns, 2001). Such factors include new knowledge (both scientific and non-scientific), the unexpected (unexpected success or failure, or an unexpected event), and changes in perception which might be caused by economic changes, together with societal, cultural and fashion changes. All of these are evident in the cases reviewed above.

\section{STRUCTURE OF THE FIRM}

The above review of reinvention shows that innovative behaviour is influenced by a variety of forces, including the business activity, the industry and the type and structure of the company. Baard (2002) argues that in small businesses the focus of the organising activity is the achievement of an effective and efficient blend of the essential ingredients for organisational success, specifically: people, physical resources and structure. In this respect small businesses

have a characteristically flat, flexible structure (Hudson, Smart and Bourne, 2001) comprised of one hierarchical level (Hankinson, Bartlett and Ducheneaut, 1997).

The other aspect of structure that appears in both the automobile industry study (Fasenfest and Jacobs, 2003) and the Warren Featherbone study (Morgenthaler, 1989) is the strong 
relationship between changes in structure and the timing of reinvention. The reinventions of the automobile industry between the 1970s and the 1990s corresponded with important shifts in the development of human capital strategies, including the flattening of the organisation, the transformation from unionised to non-unionised firms, and the replacement of existing management with a more highly educated management team. Likewise, with the Warren Featherbone case, the major innovation reinventions within the company corresponded with generational changes in management. The move into plastic nappies in 1923 occurred with the retirement of the 86 year old founder. This was followed, in 1956, by the firm's move from Michigan to Georgia, and into general clothing manufacturing, with the founder's grandson taking control of the business. This was followed in 1976 with the decision by the new vice-president, the founder's great-grandson, to discontinue the manufacture of general clothing and the move into the manufacture of medium-priced specialist baby clothes.

This review, while brief, suggests that small business can adopt competitive strategies that build on its operational capabilities. This is displayed through the firms ability to reinvent itself, and by so doing avoid the paradox of innovation.

\section{OVERLAYING THE LAYCOCK STORY}

\section{BACKGROUND}

The Laycock story is documented by Gibson (1988) in his thesis Joseph Laycock and Son Blacksmiths, Engineers and Manufactures 1889-1983, and much of the information is drawn from this work. Joseph Laycock and Son commenced operations in Bathurst, a rural community in Western New South Wales, Australia, in 1889 as a blacksmith's shop, progressively diversifying into engineering, founding, welding and, in 1918, the manufacture of bagged goods elevators and conveyors for the agricultural industry. With the success of the Laycock Elevator, the company turned to the manufacture of fruit pickers and other small farm equipment, including the patenting and manufacture of a combined cutting and threshing machine in 1922.

Following the abolition of bag stacks in favour of bulk grain storage in the 1960s, the viability of chain-type elevators declined, and the Laycock Company ceased elevator production in 1969. However, the other components, such as the light engineering section, expanded, and with the garage, continued until the death of Joe Laycock in 1986 and the closure of the company.

\section{CREATING INNOVATION}

According to the Deloitte (2005, p 9) paper, ...manufacturers that are superior at product innovation make it a formal, centralised, step-by-step business process, not a haphazardly conducted and dispersed activity.

Gibson (1988) argues that it was clear that the company was established in a way that ensured that it was capable of more than traditional blacksmithing functions. This, he claims, was based on knowledge of change taking place in England and brought to Australia by Thomas Laycock. The advent of readily available retail hardware through mass production, together with increasing levels of technological innovation in farm and town machinery, and the reduction in the traditional sources of blacksmithing work were clear indicators of a need for innovation. In other words the innovative process was planned.

Thomas Laycock's knowledge of the technical demands of the new technology, for example steam plants, modern agricultural machinery and mining machinery which were implemented 
on the farms and within industries throughout the district provided the basis for the first innovative stage of the firm's growth. Gibson (1988) indicates that the work of the machine shop, and the innovative developments, were a predominant function of the firm. In addition to innovations directly flowing from the blacksmithing function, the following were identified as part of the firm's growth and development: the foundry, oxyacetylene welding, the motor garage, the electrical and radio branch and electric arc welding.

The Deloitte (2005) study states that new product ideas must be evaluated on their own merits. A key determination of this is whether a new product concept reflects 'sustaining' or 'disruptive' innovation. The study defines these two innovation phases as: sustaining innovations which incremental improvements to existing products and disruptive innovations which substantial improvements that can displace or completely destroy existing products. The Laycock innovations encompassed both sustaining and disruptive innovation.

The sustaining or incremental innovations can be identified as: the movement into oxyacetylene welding and the transition to electric arc welding, while the establishment of garage and the electrical and radio branch are disruptive, because their establishment would draw on existing resources. In addition the company conducted its own research, design and development which had the potential for both sustaining and disruptive behaviour through resource allocation. For example, the company developed and manufactured a fence wire strainer in the early 1900s and developed and patented grain threshing machines during the 1920s. However, the introduction of the most successful innovation, the Laycock elevator and conveyor, was both sustaining and disruptive. From the disruptive perspective, the Laycock elevator had the capacity to draw on the entire resources of the firm. All components were initially manufactured in Laycock's factory, and given the small workforce, had the potential to disrupt the profitability and cash flow from other sections of the firm. The sustaining or incremental phase comes from the firm's diversification into the manufacture of threshers, patented in 1922, and of fruit graders for the agricultural industry. In addition, Laycock provided a wide variety of elevators, from its initial standard elevator, including straight gantry, special balance and midget low loader, thus building on prior innovation.

According to the Deloitte $(2005,9)$ study:

The likelihood of generating blockbuster new product concepts increases significantly when managers can tap the entire company for new ideas, as well as customers, suppliers and the external research community.

In the case of the Laycock company the management and ownership structure ensured that the entire company was involved in the many innovative decisions. This is shown in Figure 1, the timeline of innovative products. 


\section{Timeline of Innovative Products}

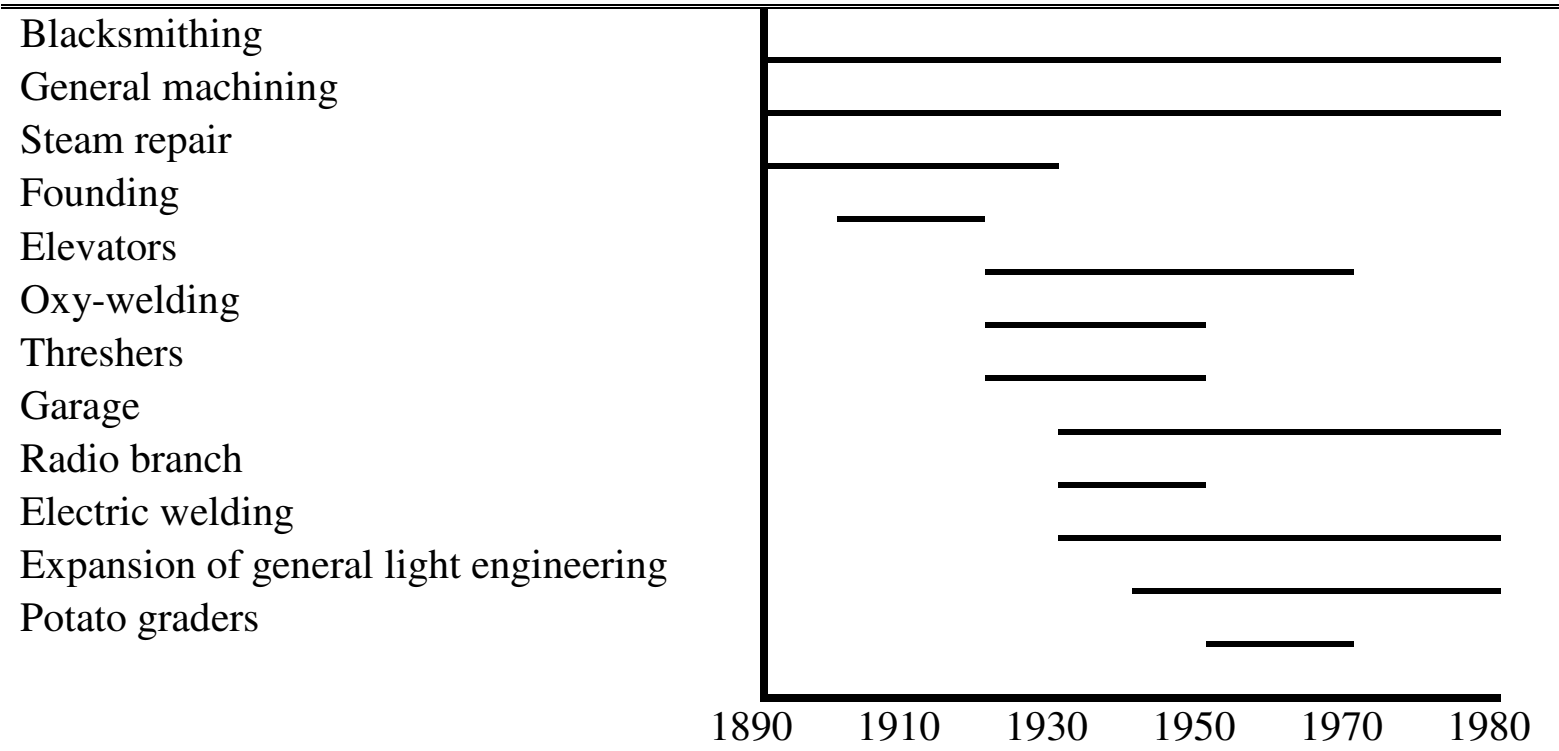

Fig. 1 (Source - Gibson, 1988, p 74)

\section{MANAGEMENT AND ORGANISATIONAL STRUCTURE}

Like many small businesses, the management structure of the Laycock enterprise was confined to family members, while other employees were either members of the Laycock family or a small number of generally unskilled full-time, part-time or casual employees. Over the 97 years of the firm's existence the number of staff averaged between three and five, including family, apprentices, part-time and casual employees. The management structure of the firm, together with the corresponding reinvention periods, is shown in Table 1. 
Table 1:

Management Structure and Periods of Reinvention of the Laycock Enterprise: 1889 to 1986

\begin{tabular}{|c|c|c|c|}
\hline Trading Name & Date & Owners & Description of Enterprise \\
\hline Thomas Laycock \& Son & 1889 & Thomas & $\begin{array}{l}\text { Practical Engineers and General } \\
\text { Blacksmiths }\end{array}$ \\
\hline Laycock Brothers & 1903 & $\begin{array}{l}\text { William, } \\
\text { Charles }\end{array}$ & $\begin{array}{l}\text { Engineers, Boilermakers and } \\
\text { General Blacksmiths }\end{array}$ \\
\hline Joseph Laycock \& Son & 1917 & $\begin{array}{l}\text { William, } \\
\text { Cyril }\end{array}$ & Engineers \\
\hline $1^{\text {st }}$ Reinvention & 1918 & \multicolumn{2}{|c|}{ Laycock Elevator } \\
\hline Joseph Laycock \& Son & 1936 & Cyril & Engineers, Electrical and Radio \\
\hline $2^{\text {nd }}$ Reinvention & 1937 & \multicolumn{2}{|c|}{$\begin{array}{l}\text { Electric Welding, Radio Branch \& } \\
\text { Garage }\end{array}$} \\
\hline Joseph Laycock \& Son & 1944 & $\begin{array}{l}\text { Cyril, } \\
\text { Joe }\end{array}$ & Engineers, Electrical and Radio \\
\hline Joseph Laycock \& Son & 1958 & $\begin{array}{l}\text { Joe, } \\
\text { Ellen }\end{array}$ & $\begin{array}{l}\text { General Mechanical Engineers } \\
\text { and Manufactures }\end{array}$ \\
\hline $3^{\text {rd }}$ Reinvention & 1959 & \multicolumn{2}{|c|}{ Expansion of general light engineering } \\
\hline Joseph Laycock \& Son & 1968 & $\begin{array}{l}\text { Joe, } \\
\text { Ellen }\end{array}$ & $\begin{array}{l}\text { General Engineers and } \\
\text { Manufactures }\end{array}$ \\
\hline Joseph Laycock \& Son & 1971 & $\begin{array}{l}\text { Joe, } \\
\text { Ellen }\end{array}$ & $\begin{array}{l}\text { Electrical Goods, Engineers and } \\
\text { Manufactures }\end{array}$ \\
\hline Joseph Laycock \& Son & 1980 & Joe & $\begin{array}{l}\text { Electrical Goods, Engineers and } \\
\text { Manufactures }\end{array}$ \\
\hline
\end{tabular}

(Source - Gibson, 1988, p 60)

Comparing the reinvention stage to the change of management structure, each change of management was followed by a period of reinvention. In 1917 Charles Laycock left the firm and moved to the nearby town of Lithgow. His place was taken by Cyril Laycock, the son of William. This coincided with the first reinvention in 1918, the introduction of the Laycock elevator. The second reinvention occurred in 1937, with the introduction of electric arc welding section, together with a radio branch and the establishment of a garage. This had been preceded by William retiring from the business due to ill health in 1936. Following William's death in 1939 Cyril's son Joe entered the business and was joined by his wife Ellen in 1958 shortly after the death of Cyril. This was followed in 1959 by the third reinvention: the expansion of the general light engineering works. This progression shows how changes in the management structure changed the work emphasis through the reinvention process to ensure the survival of the company.

\section{CONCLUSION}

Relating the sustaining and disruptive reinvention strategies of Laycock's innovative product development back to the four critical outcomes identified in the Deloitte model it can be demonstrated with respect to the first and second outcomes that: (1) the Laycock family had mastered the complexity of innovation in order to grow, as seen through their first diversification program following World War I; and (2) that the innovation was driven by changing customer demands, demonstrated by the development of the Laycock elevator. The third critical outcome, the development of a value chain that built on market complexities, can be shown through the use of the traditional value chain framework of upstream functions of 
research, development and design, the manufacturing or production function and the downstream functions of marketing, distribution and customer service. For example, the Laycock company conducted their own research, development and design, evidenced by the development of a wire strainer in the early 1900s and threshing machinery in the 1920s. All major components of the Laycock elevator, and other machinery, were manufactured in the foundry and workshop, with some castings purchased from local suppliers. With respect to downstream functions, the Laycock company marketed and distributed all of its products itself, with the exception of the Laycock elevator which was marketed through an agent. However, the company did carry out all customer service requirements (Gibson, 1988).

The final requirement for breaking the innovation paradox is the effective management of the entire product lifecycle by providing a sustainable competitive advantage built on reinvention based on sustaining and disruptive innovation. The discussion of innovative products (Figure 1) showed the Laycock company reinvented itself on three occasions, the first time in 1918 following World War I, again in the 1930s following the Great Depression and for the final time in the 1950s. According to Gibson (1988, p 107) these were deliberate strategies of reinvention:

The extension of the blacksmith's shop in the 1890s to increase machining capacity and a foundry, the adoption of new technologies such as oxy and electric welding, and the diversification of the works into a small manufacturing enterprise were deliberate strategies used by the family owners to ensure their survival.

Two issues emerged from this study. First, the problems identified in the Deloitte study are not time specific. The particular issues identified as a contemporary phenomenon were just as active in the Nineteenth and early Twentieth centuries. Second, the issues themselves do not represent a self- fulfilling prophecy. While the authors agree that innovation is the engine of growth, we disagree that small businesses place a low priority on restructuring or reinventing their organisations to bring new products and services to the market profitably.

\section{REFERENCES}

Baard, V, C., 2002. The Design and Implementation of an Interactive IT Consulting System to Improve Performance in South African Small Business. Unpublished Doctoral thesis, Central University of Technology, South Africa.

Burns, P. 2001. Entrepreneurship and Small Business, Hampshire, UK: Palgrave Publishers Ltd.

Deloitte Research, 2004. Mastering Innovation: Exploiting Ideas for Profitable Growth, New York: .Deloitte Consulting.

Fasenfest, D., \& Jacobs, J., 2003. An Anatomy of Change and Transition: The Automobile Industry of Southeast Michigan, Small Business Economics, 21(2), 153.

Fitzgerald, L., \& Moon, P., 1996. Performance Measurement in the Service Industries, London: CIMA.

Gibson, J., W., 1988. Joseph Laycock and Son - Blacksmiths, engineers and manufactures, 1889-1983. Unpublished Master of Arts thesis, University of Sydney, Australia.

Hankinson, A., Bartlett, D., \& Ducheneaut, B., 1997. The Key Factors in the Small Profiles of Small-Medium Enterprise Owner-Managers that Influence Business Performance. The UK (Rennes) SME survey 19951997: An international research project UK survey, International Journal of Entrepreneurial Behaviour \& Research, 3(3), 168.

Hatten, T. S., 2006. Small Business Management: Entrepreneurship and Beyond, Boston: Houghton Mifflin.

Hudson, M., Smart, A., \& Bourne, M., 2001. Theory and Practice in SME Performance Measurement Systems, International Journal of Operations \& Production Management, 21(8), 1096-1115.

Morgenthaler, E., 1989. An American Story: A $19^{\text {th }}$ Century Firm Shifts, Reinvents Itself and Survives 100 years, The Wall Street Journal, May 9, 1.

Mosher, D., 2000. A Renaissance in Richmond, Facilities Design \& Management, 19(9), 54-56. 
Siropolis, N.,1997. Small Business Management, $\left(6^{\text {th }}\right.$ ed), Boston: Houghton Mifflin.

Voelpel, S., C., Leibold, M., \& Tekie, E., B., 2004. The Wheel of Business Model Reinvention: How to Reshape your Business Model to Leapfrog Competitors, Journal of Change Management, 4(3), 259-276.

\begin{abstract}
About the Authors:
Dr Vicki Baard is a senior lecturer at the Australian Catholic University, North Sydney. Her research interests are in small business organisations and managerial accounting. She has had articles published in the South African Journal of Information Management Business and Informatics - Current Trends and the Small Business Monitor. Her conference presentations include the Accounting and Finance Association of Australia and New Zealand, the International Accounting Conference: Emerging Issues in International Accounting \& Business and the $51^{\text {st }}$ International Council for Small Business World Conference. Vicki received her Bachelor of Commerce from the University of Port Elizabeth, her Master of Business Administration from Oxford Brooks University (UK) and her Doctor of Technology from the Central University of Technology, South Africa.
\end{abstract}

Dr Ted Watts is a senior lecturer at the University of Wollongong. His research interests are in managerial accounting (specifically in organisational behaviour) and small business organisations. He has published a number of book chapters on a variety of managerial accounting issues, and has had articles published in Accounting Forum, Critical Perspectives on Accounting, and Financial Accountability \& Management. His conference presentations include the American Accounting Association, the Accounting and Finance Association of Australia and New Zealand, the European Accounting Association, and the Management Control Association. Ted received his Bachelor of Arts from the University of New England, Master of Commerce from the University of New South Wales, and his PhD from the University of Technology, Sydney. 